medRxiv preprint doi: https://doi.org/10.1101/2020.07.27.20162354; this version posted July 29, 2020. The copyright holder for this preprint

\title{
Non-communicable disease and the risk of infection death: a UK Biobank prospective cohort study
}

Michael Drozd ${ }^{1}$, Patrick J Lillie ${ }^{2}$, Mar Pujades-Rodriguez ${ }^{3}$, Sam Straw ${ }^{1}$, Ann W Morgan ${ }^{1,4}$, Mark T Kearney ${ }^{1}$, Klaus K Witte ${ }^{1}$, Richard M Cubbon ${ }^{1}$

${ }^{1}$ Leeds Institute of Cardiovascular and Metabolic Medicine, The University of Leeds, Leeds, United Kingdom. ${ }^{2}$ Department of Infection, Castle Hill Hospital, Hull University Hospitals NHS Trust, Kingston Upon Hull, United Kingdom. ${ }^{3}$ Leeds Institute of Health Sciences, School of Medicine, University of Leeds, Leeds United Kingdom. ${ }^{4}$ NIHR Leeds Biomedical Research Centre, Leeds Teaching Hospitals NHS Trust, United Kingdom

\section{Address for correspondence:}

Dr Richard M Cubbon

LIGHT laboratories 7.04

The University of Leeds

Clarendon Way

Leeds LS2 9JT

United Kingdom

E-mail: $\underline{\text { r.cubbon@leeds.ac.uk }}$

Telephone: +44 1133430785 
medRxiv preprint doi: https://doi.org/10.1101/2020.07.27.20162354; this version posted July 29, 2020. The copyright holder for this preprint (which was not certified by peer review) is the author/funder, who has granted medRxiv a license to display the preprint in perpetuity.

\begin{abstract}
Objectives: Non-communicable diseases (NCDs) have recently been highlighted as important risk factors for COVID-19 fatality. We set out to investigate the association between NCDs and the risk of death from any infection in the pre-COVID-19 era.
\end{abstract}

Design: Prospective population-based study

Setting: UK Biobank

Participants: 493,295 participants

Main outcome measures: Infection death prior to December $31^{\text {st }} 2019$.

Results: During 5,277,344 participant-years of follow-up, 1,385 infection deaths occurred, accounting for $5 \%$ of all deaths. Competing risks regression revealed that advancing age, male sex, smoking, socio-economic deprivation and all studied NCDs were independently associated with both the risk of infection death and non-infection death; ethnicity was associated with neither. Only smoking, socio-economic deprivation, hypertension, respiratory disease, chronic kidney disease, psychiatric disease and rheumatological disease were associated with greater hazard ratios for infection than non-infection death. Accrual of multimorbidity was also associated with a greater increases in the risk of infection death (HR 9.03 [95\% confidence interval 6.61 to 12.34] for 5+ comorbidities versus none; $p<0.001$ ), than non-infection death (HR 5.68 [95\% confidence interval 5.22 to 6.17] for 5+ comorbidities versus none; $p<0.001)$.

Conclusions: Diverse NCDs are associated with increased risk of infection death, suggesting that recently reported associations with COVID-19 death may be non-specific. Moreover, only a subset of NCDs, together with the accrual of multimorbidity, smoking and socioeconomic deprivation, are associated with greater relative risks of infection death than other causes of death. Further research is needed to define why these risk factors are biased toward infection death so that more effective preventative strategies can be targeted to high-risk groups. 
medRxiv preprint doi: https://doi.org/10.1101/2020.07.27.20162354; this version posted July 29, 2020. The copyright holder for this preprint (which was not certified by peer review) is the author/funder, who has granted medRxiv a license to display the preprint in perpetuity. It is made available under a CC-BY 4.0 International license.

\section{What is already known on this topic}

- Infection contributes to approximately one in five deaths globally and this often occurs in people with non-communicable diseases (NCDs).

- Many NCDs have recently been highlighted as risk factors for fatal COVID-19 infection.

\section{What this study adds}

- Whilst diverse NCDs are associated with greater risk of infection death, only some pose greater hazards of infection than non-infection death.

- The association of many NCDs with fatal COVID-19 infection is unlikely to be specific to this pathogen. 
medRxiv preprint doi: https://doi.org/10.1101/2020.07.27.20162354; this version posted July 29, 2020. The copyright holder for this preprint (which was not certified by peer review) is the author/funder, who has granted medRxiv a license to display the preprint in perpetuity. It is made available under a CC-BY 4.0 International license .

\section{Introduction}

Non-communicable diseases (NCDs) have recently been highlighted as important risk factors for fatal COVID-19 infection, $(1,2)$ prompting hypotheses that the virus specifically interacts with some comorbidities.(3-5) However, the wider context of infectious diseases in people with NCDs is often neglected in such proposals, in spite of this being much more common and potentially offering insight into the conserved and the disease-specific risks of COVID-19. The Global Burden of Disease Study revealed 11 million sepsis-related deaths during 2017, amounting to almost $20 \%$ of all deaths.(6) Sepsis-related death was more common in men, the elderly (and infants), and socio-economically deprived populations. Moreover, around $40 \%$ of cases had an NCD listed as the underlying cause of death, with cardiovascular diseases, diabetes, liver disease, COPD and kidney disease all being commonly implicated. Hence, there are clear parallels between the risk factors for sepsis death and COVID-19 death. In spite of a $30 \%$ reduction in global sepsis-related deaths between 1990 and 2017,(6) the issue of lifethreatening infection in people with NCDs is likely to become more important in the context of globally increasing rates of multimorbidity and anti-microbial resistance. $(7,8)$ Moreover, as populations become more affluent, NCDs are proportionally more common as an underlying cause of sepsis death,(6) underlining the growing relevance to many 'economically developing' populations. In spite of the scale and impact of this issue, little prospective research is published about the independent risks posed by specific NCDs, and multimorbidity, for infection-related death. To address this, we analysed the wellcharacterised UK Biobank cohort study using follow-up data prior to the COVID-19 pandemic.

\section{Methods}

Study design and data collection: The UK Biobank (UKB) cohort is a population-based prospective study that consists of 502,505 people aged between $37-73$ years. Participants were recruited between 2006 and 2010, and attended one of 22 assessment centres across England, Scotland and Wales. Baseline biological measurements were recorded, and participants completed a touchscreen and nurse-led questionnaire, as described elsewhere.(9) UKB received ethical approval from the NHS Research Ethics Service (11/NW/0382); we conducted this analysis under application number 59585. All participants provided written informed consent. There was no patient and public involvement in the planning of this analysis. 
medRxiv preprint doi: https://doi.org/10.1101/2020.07.27.20162354; this version posted July 29, 2020. The copyright holder for this preprint (which was not certified by peer review) is the author/funder, who has granted medRxiv a license to display the preprint in perpetuity. It is made available under a CC-BY 4.0 International license .

Assessment of demographic factors and morbidity: Age, sex, ethnicity and socioeconomic status were considered as potential risk factors. Age at recruitment was categorised into the following groups: $<45,45$ to $<50,50$ to $<55,55$ to $<59,60$ to $<64$ and $65+$. Ethnicity was participant-classified within UKB-defined categories of white, mixed, Asian or British Asian, black or British black, Chinese or other ethnic group. Self-reported smoking status was reported as never, previous or current. Socioeconomic deprivation (SED) was classified into quintiles using the Townsend score. Obesity was classified using the World Health Organisation's categorisation according to body mass index: class $1\left(30.0-34.9 \mathrm{~kg} / \mathrm{m}^{2}\right)$, class $2(35.0$-39.9), class $3(\geq 40)$. Self-reported medical conditions recorded at study recruitment during face-to-face interview with a nurse were used to classify morbidities into groups (described in Supplemental Table 1). We selected a range of morbidities that represent a broad spectrum of common disease groups, including: hypertension, chronic heart disease (ischaemic heart disease and heart failure), chronic respiratory disease, diabetes, prior cancer, chronic liver disease, chronic kidney disease, prior stroke/TIA, other neurological disease, psychiatric disease and rheumatological disease (chronic inflammatory and autoimmune rheumatic disease, not non-inflammatory disorders).(10) The number of these comorbidities was calculated for each participant. Missing data for comorbidities $(n=863)$, body mass index $(n=3,106)$, smoking status $(n=2,949)$, ethnicity $(n=2,777)$ and SED $(624)$ resulted in exclusion of those participants from the analysis.

Mortality ascertainment: Mortality information was recorded through linkage to national death registries. In the present analysis, we censored deaths up until $31^{\text {st }}$ December 2019 to ensure this was before the first reported case of COVID-19 in the United Kingdom.(11) Deaths were classified using ICD-10 codes for the main cause of death as infection-related (described in Supplemental Table 2) or non-infection. Loss to follow-up or withdrawal of consent resulted in 863 participants being excluded from the analysis.

Statistical analysis: Continuous variables are presented as mean (standard deviation) and categorical variables as number (percentage). Adjusted cause-specific mortality hazard ratios were estimated using Fine and Gray competing risk regression modelling,(12) with infection deaths as the events of interest and non-infection deaths as competing events, or vice versa, 
medRxiv preprint doi: https://doi.org/10.1101/2020.07.27.20162354; this version posted July 29, 2020. The copyright holder for this preprint (which was not certified by peer review) is the author/funder, who has granted medRxiv a license to display the preprint in perpetuity. It is made available under a CC-BY 4.0 International license .

with the same adjustment variables. Models were adjusted for all covariates, including: age, sex, SED, smoking, obesity, hypertension, chronic heart disease, chronic respiratory disease, diabetes, cancer, chronic liver disease, chronic kidney disease, prior stroke/TIA, other neurological disease, psychiatric disorder and rheumatological disease (or the number of comorbidities, up to a maximum of 5 , in place of obesity, hypertension, chronic heart disease, chronic respiratory disease, diabetes, cancer, chronic liver disease, chronic kidney disease, prior stroke/TIA, other neurological disease, psychiatric disorder and rheumatological disease). All tests were 2 -sided and statistical significance was defined as $p<0.05$. All statistical analyses were performed using Stata (StataCorp LP, College Station, USA; version 16.1) and R (http://cran.r-project.org/; version 4.0.2).

\section{Results}

Amongst the UK Biobank cohort of 502,505 people, we excluded 9,210 (1.8\%) due to missing baseline data or long-term follow-up data, as described in the methods section. Within the study sample of 493,295 people, 1,385 infection deaths occurred during 5,277,344 personyears of follow-up (10.9, IQR 10.1 - 11.6), accounting for approximately $5 \%$ of the total 27,729 deaths (Figure 1a). The commonest fatal infections involved the lower respiratory tract $(60.7 \%)$, gastrointestinal tract (14.2\%) and genitourinary tract (5.9\%); data for all causes are presented in Figure 1b (and Supplemental Table 3). Compared to survivors, people experiencing infection death were older, more often male, more socio-economically deprived, more commonly smoked, and were more likely to have a wide range of NCDs (Table 1). Broadly similar differences were observed when comparing survivors with people experiencing non-infection death, although cancer was markedly more common in people experiencing non-infection death.

To define the association between NCDs and infection-death, whilst also accounting for the loss of participants due to non-infection death, we performed competing risks analyses to derive cause-specific hazard ratios. As shown in Figure 2 (and Supplemental Table 4), advancing age, male sex, advanced obesity, smoking, SED and all individual NCDs were independently associated with the risk of infection death. However, there was no clear association between any ethnic group and altered risk of infection death. Similarly, for noninfection death, advancing age, male sex, obesity, smoking, socio-economic deprivation and 
medRxiv preprint doi: https://doi.org/10.1101/2020.07.27.20162354; this version posted July 29, 2020. The copyright holder for this preprint (which was not certified by peer review) is the author/funder, who has granted medRxiv a license to display the preprint in perpetuity. It is made available under a CC-BY 4.0 International license .

all individual NCDs were also independently associated with the risk of infection death. Again, there was no clear association between any ethnic group and altered risk of non-infection death. However, the hazards associated with smoking, socio-economic deprivation, class 3 obesity, hypertension, chronic respiratory disease, chronic kidney disease, psychiatric disease and rheumatological disease were greater for infection than non-infection death, whilst the converse was apparent for cancer.

To explore the impact of multimorbidity, we conducted alternate competing risks analyses including the number of NCDs, rather than individual diseases, whilst also accounting for age, sex, ethnicity and socio-economic deprivation. As shown in Figure 3 (and Supplemental Table 5), this revealed a clear gradient of increasing risk of infection death as the number of NCDs increased. Notably, whilst gradient of increasing risk of non-infection death was also observed, this was less steep than for infection death.

\section{Discussion}

We have conducted the largest ever prospective analysis of risk factors for infection death in people recruited in a community setting. Infection death was more common in men, with advancing age and increasing SED. All studied NCDs were also independently associated with increased risk of infection death, as was the accrual of multimorbidity. Risk factors for infection death were similar to those reported for COVID-19 death, although most of these were associated with similar hazards of infection and non-infection death. However, some conferred greater risks of infection death, including: advancing age, smoking, socio-economic deprivation, class 3 obesity, hypertension, chronic respiratory disease, chronic kidney disease, psychiatric disease, rheumatological disease, and the accrual of multimorbidity. These highrisk populations may benefit from strategies to prevent or more effectively treat infection.

The existing literature supports the importance of infection as a cause of death in populations with many of the individual NCDs we have studied, including people with chronic heart failure; $(13,14)$ diabetes,(15) chronic kidney disease,(16) liver disease,(17) rheumatological disease(18), and neurodegenerative disorders (19) Our analysis supports these diseasespecific data, but has the advantage of considering both the additive and independent risk of infection death attributable to multiple NCDs in the same population. Notably, whilst the 
medRxiv preprint doi: https://doi.org/10.1101/2020.07.27.20162354; this version posted July 29, 2020. The copyright holder for this preprint (which was not certified by peer review) is the author/funder, who has granted medRxiv a license to display the preprint in perpetuity. It is made available under a CC-BY 4.0 International license .

accumulation of multimorbidity has been linked with greater risks of all-cause, cardiovascular and cancer death,(10) our finding regarding a greater risk of infection than non-infection death are novel. Regarding the larger hazard of infection death associated with SED, whilst residual confounding could explain this association, socio-economic interventions have played major roles in addressing past and present infectious diseases. $(20,21)$

The COVID-19 pandemic has brought fresh attention to the adverse outcomes experienced by people with NCDs who develop infectious diseases. Whilst there are some disagreements regarding specific risk factors, probably reflecting differing methods, the COVID-19 literature broadly suggests that ageing, male sex, socio-economic deprivation, and accrual of NCDs increase the risk of adverse outcomes. $(1,22)$ The broad agreement with our analysis of risk factors for death related to infection in the pre-COVID-19 era suggests common underlying factors and solutions to these problems. One notable difference is that ethnicity was not associated with infection death in our adjusted analyses, but has frequently been identified as a risk factor for adverse COVID-19 outcomes,(23) including in the UK Biobank cohort,(24) although not all studies agree.(1) Again, this disagreement may relate to methodological issues, but could also support COVID-19 differentially impacting specific ethnic groups.

It is important to acknowledge the potential limitations of our work. Firstly, UK Biobank is not a nationally representative cohort,(25) so caution should be applied in extrapolating data on infection death prevalence. However, our finding that infections account for $5 \%$ of all deaths is broadly in keeping with the Global Burden of Disease data on sepsis-death in the United Kingdom.(6) It is also important to highlight the challenges of death certification data, which do not always encompass the complex factors contributing to death. Similarly, the classification of NCD status in UK Biobank often relies on participant-reported data, and so may lack the fidelity of other approaches, although available adjudication data suggest these are valid.(26) Moreover, the classification of most NCDs as being present or absent neglects the heterogeneity within these, which may have an important influence on risk of infectiondeath. Finally, as with any observational study, it is important not to draw causal inferences from our data, although our findings raise many important and testable hypotheses. 
medRxiv preprint doi: https://doi.org/10.1101/2020.07.27.20162354; this version posted July 29, 2020. The copyright holder for this preprint (which was not certified by peer review) is the author/funder, who has granted medRxiv a license to display the preprint in perpetuity. it is made available under a CC-BY 4.0 International license-

Ongoing work is needed to understand the relative importance of NCDs causing recurrent infections, versus increasing the risk of death during any single episode, to the overall risk of infection death. Future research should also define mechanisms linking NCDs (and their treatment) to infection death e.g. via altered immune responses to vaccination and infection, inflammatory responses to pathogens, and physiological responses during infection/sepsis. Addressing these uncertainties will help to inform the selection of therapeutic strategies for clinical trials; these could include: specific primary and/or secondary infection prevention measures; improved access to care, monitoring for early detection of infection and initiation of appropriate antimicrobial treatment; improved use of high dependency care. However, even without further research, our data are important to health care professionals and people with NCDs, who should be alert to the importance of infection to adverse outcomes. 
medRxiv preprint doi: https://doi.org/10.1101/2020.07.27.20162354; this version posted July 29, 2020. The copyright holder for this preprint (which was not certified by peer review) is the author/funder, who has granted medRxiv a license to display the preprint in perpetuity. $\mathrm{t}$ is made available under a CC-BY 4.0 International license.

Acknowledgements: This research has been conducted using the UK Biobank Resource. MD is supported by a British Heart Foundation Clinical Research Training Fellowship. AM has received salary support from the National Institute for Health Research and the UK Medical Research Council. MTK is a British Heart Foundation professor. RMC was supported by a British Heart Foundation Intermediate Clinical Research Fellowship.

Funding Statement: No specific funding was required for this research, but some authors are or were paid by the British Heart Foundation. At no time did any authors, nor their institutions, receive other payment or services from a third party for any aspect of the submitted work.

Competing Interest Statement: AM has undertaken consultancy work in relation to giant cell arteritis for Roche, Chugai, GlaxoSmithKline, Sanofi and Regeneron Pharmaceuticals, with all funding paid directly into a research account. MTK has received speaker fees from Merck, Novo Nordisk and unrestricted research awards from Medtronic. All other authors have no disclosures. KKW has received speaker fees from Medtronic, Livanova, St. Jude Medical, Pfizer, Bayer and BMS.

Transparency Statement: RC affirms that the manuscript is an honest, accurate, and transparent account of the study being reported; no important aspects of the study have been omitted; there are no discrepancies from the study as originally planned.

Contributorship Statement: Guarantors - MD and RC; Study conception - MD and RC; Data analysis - MD; Manuscript drafting - MD and RC; Critical revision of manuscript: PJL, MPR, AWM, SS, MTK, KKW. The corresponding author attests that all listed authors meet authorship criteria and that no others meeting the criteria have been omitted. 
medRxiv preprint doi: https://doi.org/10.1101/2020.07.27.20162354; this version posted July 29, 2020. The copyright holder for this preprint (which was not certified by peer review) is the author/funder, who has granted medRxiv a license to display the preprint in perpetuity.

\section{References}

1. Williamson EJ, Walker AJ, Bhaskaran K, Bacon S, Bates C, Morton CE, et al. OpenSAFELY: factors associated with COVID-19 death in 17 million patients. Nature 2020 [Online ahead of print].

2. Petrilli CM, Jones SA, Yang J, Rajagopalan H, O'Donnell L, Chernyak Y, et al. Factors associated with hospital admission and critical illness among 5279 people with coronavirus disease 2019 in New York City: prospective cohort study. BMJ 2020; 369: m1966.

3. De Lorenzo A, Escobar S, Tibiriçá E. Systemic endothelial dysfunction: A common pathway for COVID-19, cardiovascular, and metabolic diseases. Nutr Metab Cardiovas Dis 20203 0(8): 1401-1402

4. Li H, Liu L, Zhang D, Xu J, Dai H, Tang N, et al. SARS-CoV-2 and viral sepsis: observations and hypotheses. Lancet 2020; 395(10235): 1517-20.

5. Cinti S, Graciotti L, Giordano A, Valerio A, Nisoli E. COVID-19 and fat embolism: a hypothesis to explain the severe clinical outcome in people with obesity. Int J Obes 2020; 44(8): 1800-1802.

6. Rudd KE, Johnson SC, Agesa KM, Shackelford KA, Tsoi D, Kievlan DR, et al. Global, regional, and national sepsis incidence and mortality, 1990-2017: analysis for the Global Burden of Disease Study. Lancet 2020; 395(10219): 200-11.

7. Laxminarayan R, Duse A, Wattal C, Zaidi AKM, Wertheim HFL, Sumpradit N, et al. Antibiotic resistance - the need for global solutions. Lancet Infect Dis 2013; 13(12): 1057-98.

8. Garin N, Koyanagi A, Chatterji S, Tyrovolas S, Olaya B, Leonardi M, et al. Global Multimorbidity Patterns: A Cross-Sectional, Population-Based, Multi-Country Study. J Gerontol A Biol Sci Med Sci 2015; 71(2): 205-14.

9. Sudlow C, Gallacher J, Allen N, Beral V, Burton P, Danesh J, et al. UK Biobank: An Open Access Resource for Identifying the Causes of a Wide Range of Complex Diseases of Middle and Old Age. PLoS Med 2015; 12(3): 1-10.

10. Jani BD, Hanlon P, Nicholl BI, McQueenie R, Gallacher KI, Lee D, et al. Relationship between multimorbidity, demographic factors and mortality: findings from the UK Biobank cohort. BMC Med 2019; 17(1): 74. 
medRxiv preprint doi: https://doi.org/10.1101/2020.07.27.20162354; this version posted July 29, 2020. The copyright holder for this preprint (which was not certified by peer review) is the author/funder, who has granted medRxiv a license to display the preprint in perpetuity. It is made available under a CC-BY 4.0 International license .

11. Moss $P$, Barlow $G$, Easom N, Lillie $P$, Samson A. Lessons for managing highconsequence infections from first COVID-19 cases in the UK. Lancet 2020; 395(10227): e46.

12. Fine JP, Gray RJ. A Proportional Hazards Model for the Subdistribution of a Competing Risk. J Am Stat Assoc 1999; 94(446): 496-509.

13. Drozd M, Garland E, Walker AMN, Slater TA, Koshy A, Straw S, et al. Infection-Related Hospitalization in Heart Failure With Reduced Ejection Fraction. Circ Heart Fail. 2020; 13(5): e006746.

14. Walker A, Drozd M, Hall M, Patel P, Paton M, Lowry J, et al. Prevalence and Predictors of Sepsis Death in Patients With Chronic Heart Failure and Reduced Left Ventricular Ejection Fraction. J Am Heart Assoc 2018 7(20): e009684.

15. Carey IM, Critchley JA, DeWilde S, Harris T, Hosking FJ, Cook DG. Risk of Infection in Type 1 and Type 2 Diabetes Compared With the General Population: A Matched Cohort Study. Diabetes Care 2018; 41(3): 513-21.

16. Wang HE, Gamboa C, Warnock DG, Muntner P. Chronic Kidney Disease and Risk of Death from Infection. Am J Nephrol 2011; 34(4): 330-6.

17. Arvaniti V, D’Amico G, Fede G, Manousou P, Tsochatzis E, Pleguezuelo M, et al. Infections in Patients With Cirrhosis Increase Mortality Four-Fold and Should Be Used in Determining Prognosis. Gastroenterology 2010; 139(4): 1246-1256.

18. Wu J, Keeley A, Mallen C, Morgan AW, Pujades-Rodriguez M. Incidence of infections associated with oral glucocorticoid dose in people diagnosed with polymyalgia rheumatica or giant cell arteritis: a cohort study in England. CMAJ 2019; 191(25): E680-8.

19. Manabe T, Fujikura Y, Mizukami K, Akatsu H, Kudo K. Pneumonia-associated death in patients with dementia: A systematic review and meta-analysis. PLoS One 2019; 14(3): 1-14.

20. Braveman P. Accumulating Knowledge on the Social Determinants of Health and Infectious Disease. Public Health Rep 2011; 126(S3): 28-30.

21. Semenza JC, Suk JE, Tsolova S. Social determinants of infectious diseases: a public health priority. Eurosurveillance 2010; 15(27): 2-4.

22. Docherty AB, Harrison EM, Green CA, Hardwick HE, Pius R, Norman L, et al. Features of 20133 UK patients in hospital with covid-19 using the ISARIC WHO Clinical 
medRxiv preprint doi: https://doi.org/10.1101/2020.07.27.20162354; this version posted July 29, 2020. The copyright holder for this preprint

(which was not certified by peer review) is the author/funder, who has granted medRxiv a license to display the preprint in perpetuity. It is made available under a CC-BY 4.0 International license .

Characterisation Protocol: prospective observational cohort study. BMJ 2020; 369: m1985.

23. Patel P, Hiam L, Sowemimo A, Devakumar D, McKee M. Ethnicity and covid-19. BMJ 2020; 369: m2282

24. Niedzwiedz CL, O’Donnell CA, Jani BD, Demou E, Ho FK, Celis-Morales C, et al. Ethnic and socioeconomic differences in SARS-CoV-2 infection: prospective cohort study using UK Biobank. BMC Med 2020; 18(1): 160.

25. Fry A, Littlejohns TJ, Sudlow C, Doherty N, Adamska L, Sprosen T, et al. Comparison of Sociodemographic and Health-Related Characteristics of UK Biobank Participants With Those of the General Population. Am J Epidemiol 2017; 186(9): 1026-34.

26. Eastwood S V, Mathur R, Atkinson M, Brophy S, Sudlow C, Flaig R, et al. Algorithms for the Capture and Adjudication of Prevalent and Incident Diabetes in UK Biobank. PLoS One 2016; 11(9): 1-18. 
medRxiv preprint doi: https://doi.org/10.1101/2020.07.27.20162354; this version posted July 29, 2020. The copyright holder for this preprint (which was not certified by peer review) is the author/funder, who has granted medRxiv a license to display the preprint in perpetuity.

Table 1: Participant characteristics at recruitment

\begin{tabular}{|c|c|c|c|}
\hline & $\begin{array}{l}\text { Survivors } \\
n=465,566\end{array}$ & $\begin{array}{l}\text { Infection death } \\
\qquad n=1,385\end{array}$ & $\begin{array}{c}\text { Non-infection death } \\
n=26,344\end{array}$ \\
\hline \multicolumn{4}{|l|}{ Age } \\
\hline$<45$ & $50,081(10.8 \%)$ & $23(1.7 \%)$ & 599 (2.3\%) \\
\hline 45 to $<50$ & 63,617 (13.7\%) & $40(2.9 \%)$ & 1205 (4.6\%) \\
\hline 50 to $<55$ & 72,683 (15.6\%) & $103(7.4 \%)$ & 2161 (8.2\%) \\
\hline 55 to $<60$ & 85,185 (18.3\%) & 195 (14.1\%) & 3881 (14.7\%) \\
\hline 60 to $<65$ & 111,064 (23.9\%) & $383(27.7 \%)$ & 7924 (30.1\%) \\
\hline $65+$ & 82,936 (17.8\%) & $641(46.3 \%)$ & $10,574(40.1 \%)$ \\
\hline \multicolumn{4}{|l|}{ Sex } \\
\hline Female & $257,683(55.4 \%)$ & $543(39.2 \%)$ & $10,632(40.4 \%)$ \\
\hline Male & $207,883(44.7 \%)$ & $842(60.8 \%)$ & $15,712(59.6 \%)$ \\
\hline \multicolumn{4}{|l|}{ Ethnicity } \\
\hline White & $440,402(94.6 \%)$ & 1,344 (97.0\%) & $25,453(96.6 \%)$ \\
\hline Mixed & 2,797 (0.6\%) & $4(0.3 \%)$ & 104 (0.4\%) \\
\hline Asian & $9,106(2 \%)$ & 19 (1.4\%) & $338(1.3 \%)$ \\
\hline Black & 7,534 (1.6\%) & $12(0.9 \%)$ & $249(1 \%)$ \\
\hline Chinese & $1,502(0.3 \%)$ & $1(0.1 \%)$ & $37(0.1 \%)$ \\
\hline Other & 4,225 (0.9\%) & $5(0.4 \%)$ & $163(0.6 \%)$ \\
\hline \multicolumn{4}{|l|}{ SED quintile } \\
\hline 1 (least deprived) & 93,973 (20.2\%) & $170(12.3 \%)$ & 4,555 (17.3\%) \\
\hline 2 & 93,776 (20.1\%) & 206 (14.9\%) & 4,640 (17.6\%) \\
\hline 3 & $93,483(20.1 \%)$ & 240 (17.3\%) & 4,936 (18.7\%) \\
\hline 4 & $93,112(20 \%)$ & 295 (21.3\%) & 5,254 (19.9\%) \\
\hline 5 (most deprived) & 91,222 (19.6\%) & 474 (34.2\%) & 6,959 (26.4\%) \\
\hline \multicolumn{4}{|l|}{ Smoking } \\
\hline Never & $259,721(55.8 \%)$ & 439 (31.7\%) & $10,072(38.2 \%)$ \\
\hline Former & $159,304(34.2 \%)$ & $582(42.0 \%)$ & $11,128(42.2 \%)$ \\
\hline Current & $46,541(10 \%)$ & 364 (26.3\%) & $5,144(19.5 \%)$ \\
\hline \multicolumn{4}{|l|}{ Obesity } \\
\hline Not obese & $352374(75.7 \%)$ & $928(67.0 \%)$ & 18,206 (69.1\%) \\
\hline Class 1 & 81466 (17.5\%) & $281(20.3 \%)$ & $5,471(20.8 \%)$ \\
\hline Class 2 & 22992 (4.9\%) & 96 (6.9\%) & $1,828(6.9 \%)$ \\
\hline Class 3 & 8734 (1.9\%) & 80 (5.8\%) & 839 (3.2\%) \\
\hline Hypertension & $119,429(25.7 \%)$ & 667 (48.2\%) & 10,701 (40.6\%) \\
\hline Chronic cardiac disease & $19,671(4.2 \%)$ & 250 (18.1\%) & $3,546(13.5 \%)$ \\
\hline
\end{tabular}


medRxiv preprint doi: https://doi.org/10.1101/2020.07.27.20162354; this version posted July 29, 2020. The copyright holder for this preprint (which was not certified by peer review) is the author/funder, who has granted medRxiv a license to display the preprint in perpetuity. It is made available under a CC-BY 4.0 International license .

\begin{tabular}{lccc} 
Chronic respiratory & & & \\
disease & $59,068(12.7 \%)$ & $385(27.8 \%)$ & $4,451(16.9 \%)$ \\
Diabetes & $21,206(4.6 \%)$ & $228(16.5 \%)$ & $3,317(12.6 \%)$ \\
Cancer & $35,818(7.7 \%)$ & $177(12.8 \%)$ & $5,012(19 \%)$ \\
Chronic liver disease & $797(0.2 \%)$ & $12(0.9 \%)$ & $147(0.6 \%)$ \\
Chronic kidney disease & $1,001(0.2 \%)$ & $29(2.1 \%)$ & $241(0.9 \%)$ \\
Prior stroke/TIA & $7,214(1.6 \%)$ & $104(7.5 \%)$ & $1,274(4.8 \%)$ \\
Other neurology disease & $5,726(1.2 \%)$ & $57(4.1 \%)$ & $763(2.9 \%)$ \\
Psychiatric disorder & $27,578(5.9 \%)$ & $141(10.2 \%)$ & $1,930(7.3 \%)$ \\
Rheumatological disease & $10,023(2.2 \%)$ & $97(7 \%)$ & $972(3.7 \%)$ \\
\hline
\end{tabular}

Legend: Participant characteristics are presented as number (\% within column category).

SED - socio-economic deprivation, BMI - body mass index, TIA - transient ischaemic attack. 
medRxiv preprint doi: https://doi.org/10.1101/2020.07.27.20162354; this version posted July 29, 2020. The copyright holder for this preprint (which was not certified by peer review) is the author/funder, who has granted medRxiv a license to display the preprint in perpetuity. It is made available under a CC-BY 4.0 International license .

Figure 1: Timing and classification of infection deaths

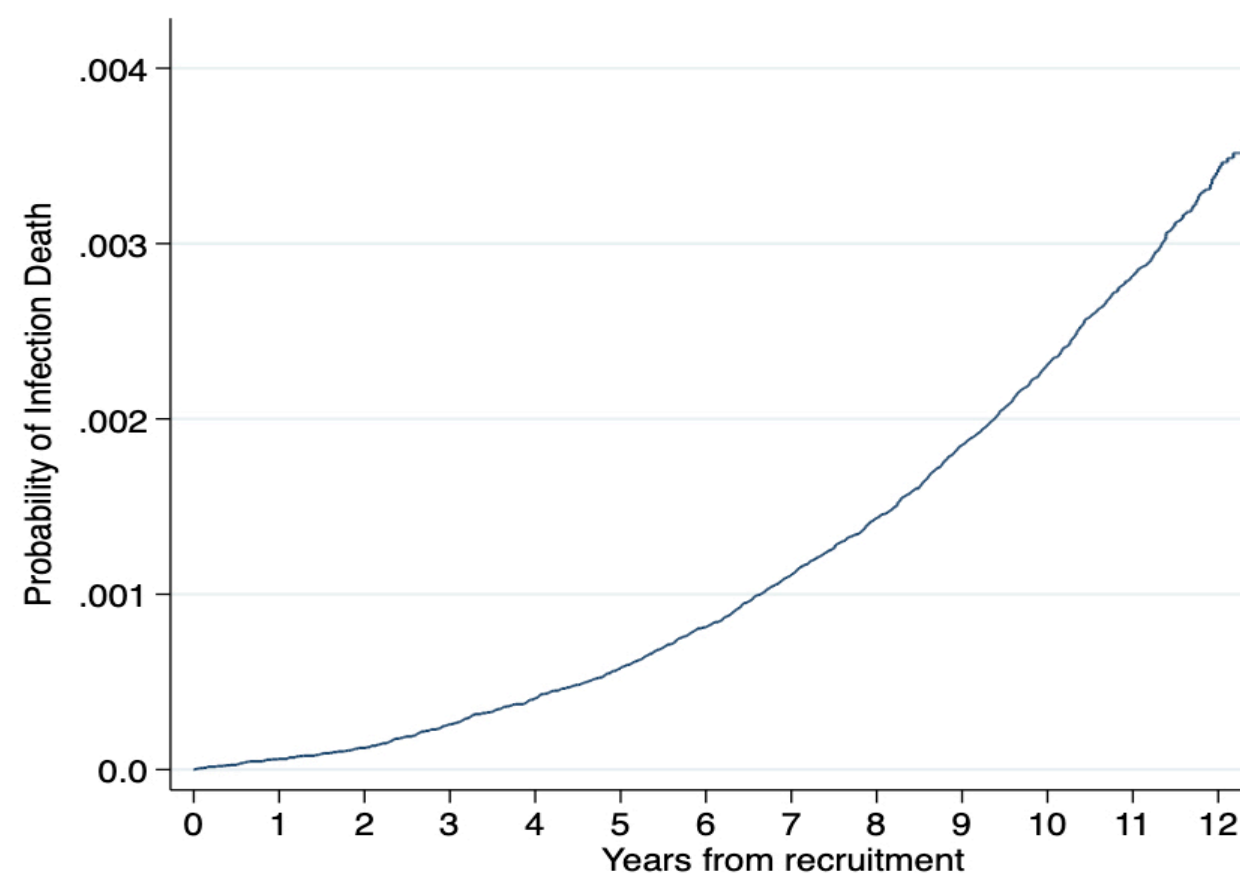

A

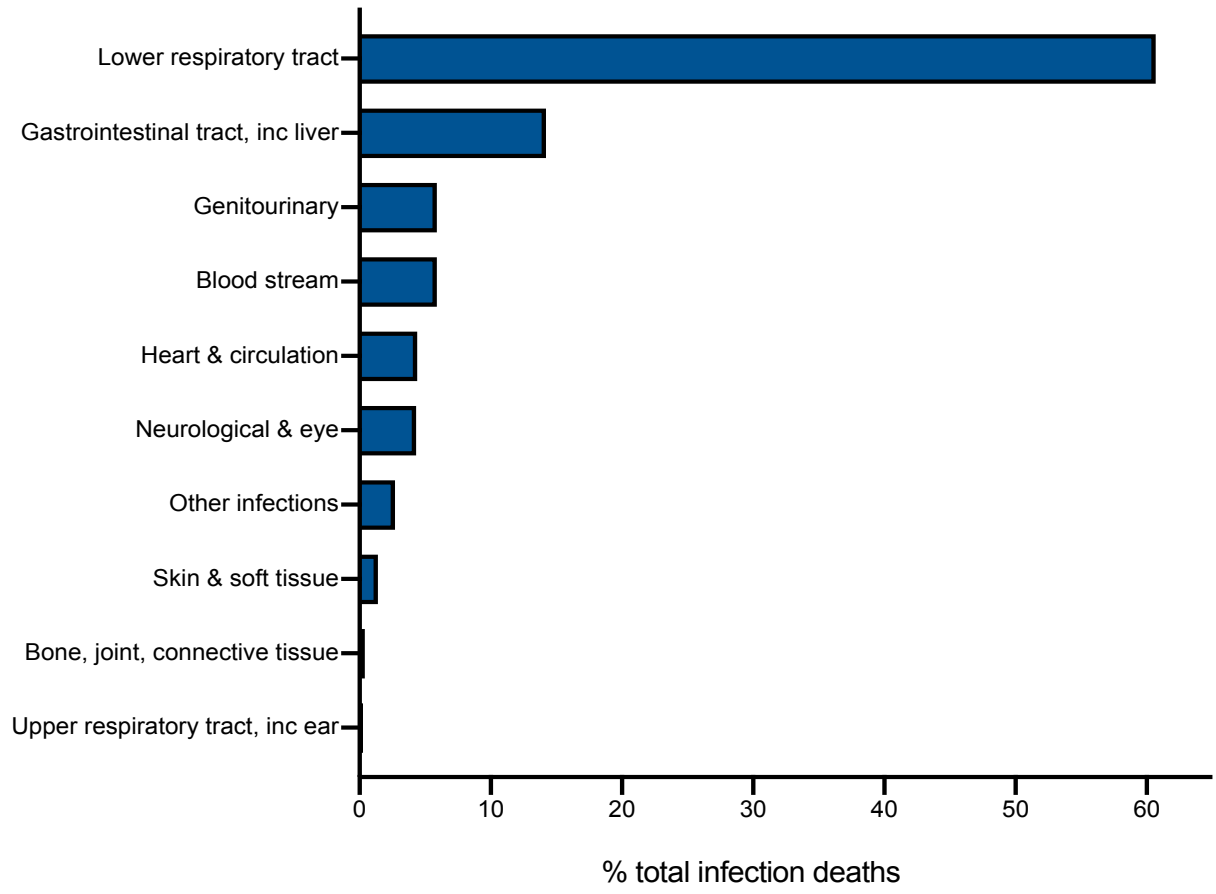

B

Legend: A) Cumulative incidence function illustrating cumulative infection deaths during follow-up. B) Bar chart illustrating classification of infection deaths. 
medRxiv preprint doi: https://doi.org/10.1101/2020.07.27.20162354; this version posted July 29, 2020. The copyright holder for this preprint (which was not certified by peer review) is the author/funder, who has granted medRxiv a license to display the preprint in perpetuity. It is made available under a CC-BY 4.0 International license.

Figure 2: Association between participant characteristics and the risk of infection or noninfection death

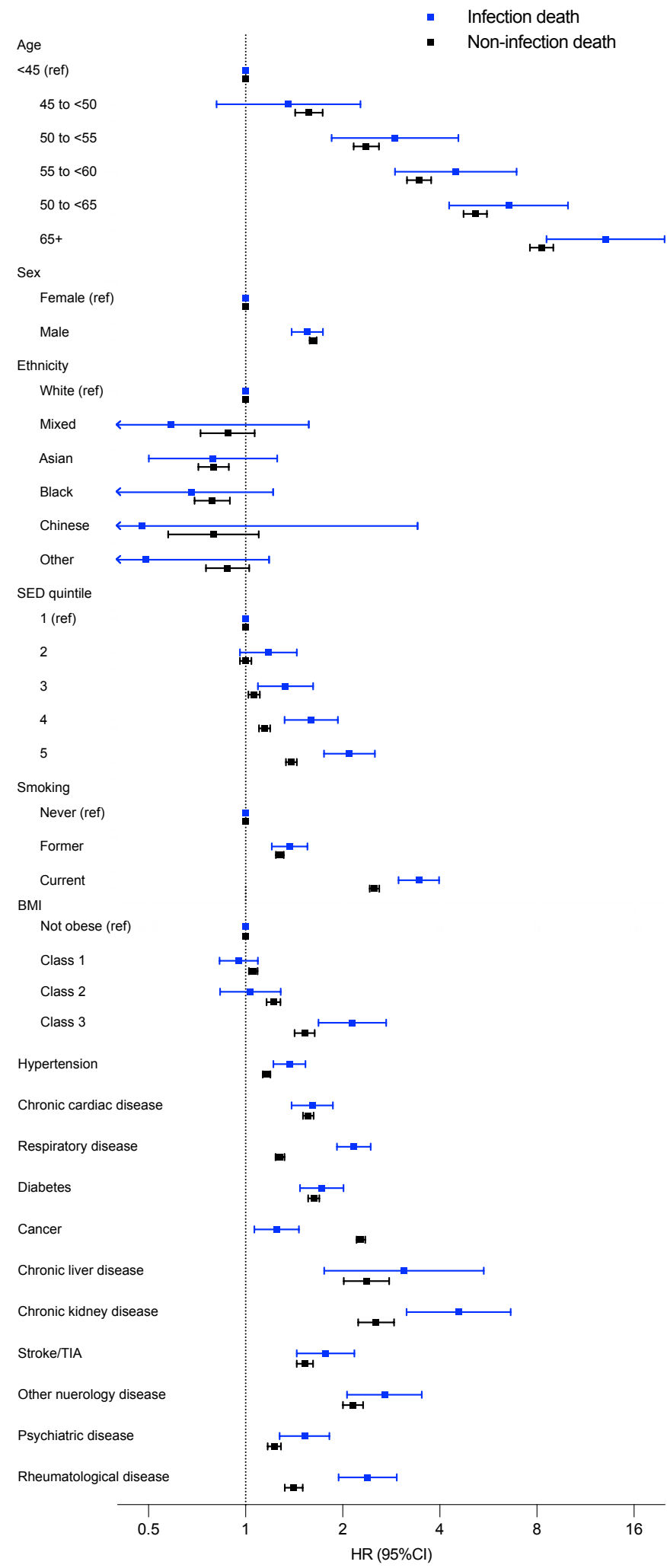

Legend: Forest plot illustrating hazard ratios and 95\% confidence intervals for infection (blue) or non-infection (black) death in multivariate competing risks regression analysis. 
medRxiv preprint doi: https://doi.org/10.1101/2020.07.27.20162354; this version posted July 29, 2020. The copyright holder for this preprint (which was not certified by peer review) is the author/funder, who has granted medRxiv a license to display the preprint in perpetuity. It is made available under a CC-BY 4.0 International license .

Figure 3: Association between multimorbidity and the risk of infection or non-infection death

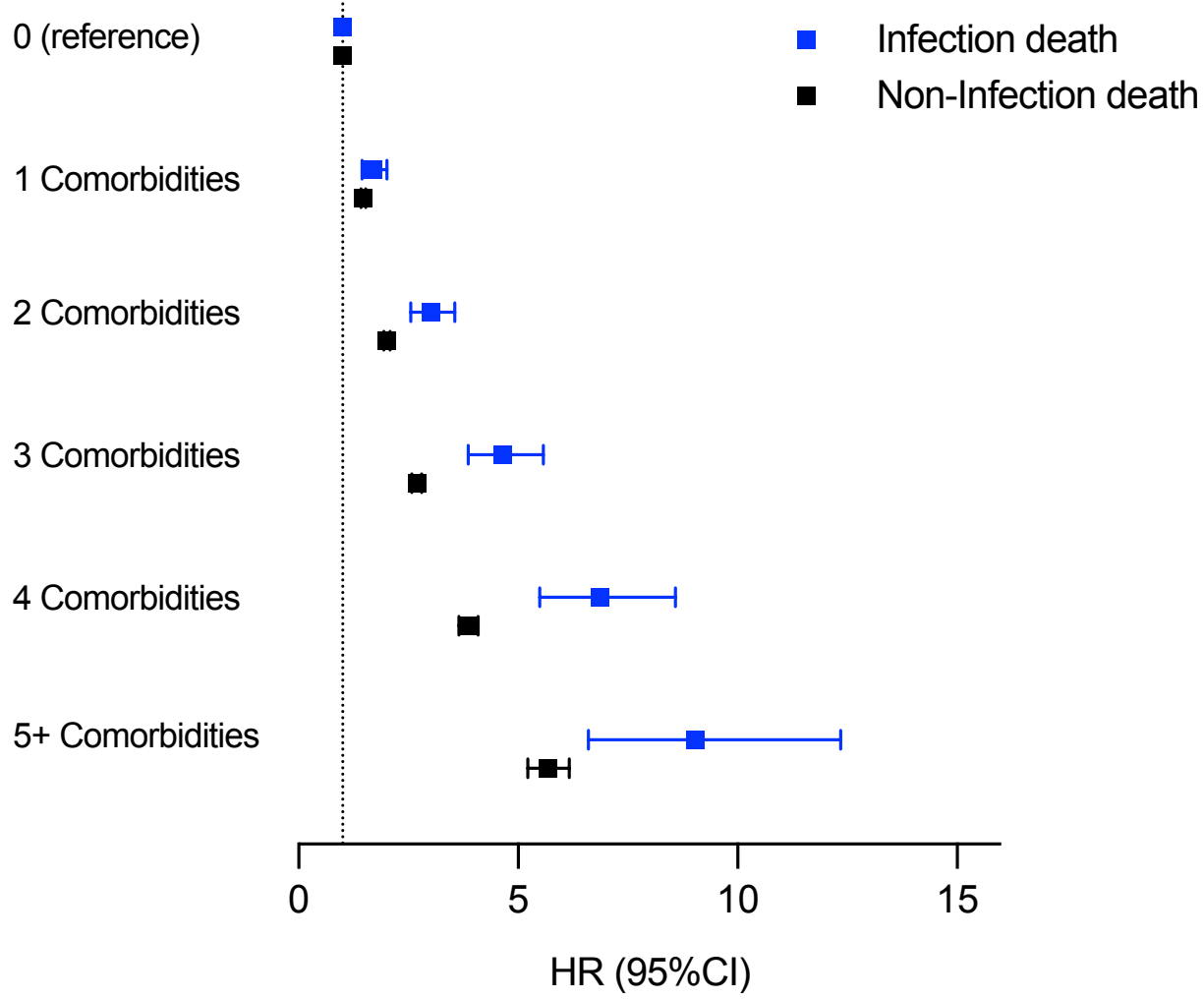

Legend: Forest plot illustrating hazard ratios and $95 \%$ confidence intervals for infection (blue) or non-infection (black) death in multivariate competing risks regression analysis, adjusting for age, sex, socio-economic deprivation and ethnicity. 